\title{
HUBUNGAN KADAR LIMFOSIT DAN MONOSIT DENGAN TINGKAT KEPARAHAN PADA PASIEN TUBERKULOSIS EKSTRA PARU
}

\author{
Raihanah Nabilah ${ }^{1}$ \\ ${ }^{1}$ Program Pendidikan Dokter, Fakultas Kedokteran, Universitas Lampung
}

\begin{abstract}
Relationship of Lymphocyte and Monocyte Levels with Severity in Patients with Extra Lung Tuberculosis. Tuberculosis (TB) is still a health problem in the world, which ranks second as the most infectious disease that causes death after Human Immunodeficiency Virus (HIV). Mycobacterium tuberculosis attacks the organs of the lungs $80 \%$, while the other $20 \%$ attacks external organs such as the lining of the brain, bones, kidneys, abdominal cavity, lymph nodes or other body parts including the skin and pleura. The spread of TB to extrapulmonary organs depends on the cellular immune system, especially T-helper cells (TH1 response). Cellular immunity plays a more active role than humoral because cellular immunity as the main function of leukocytes is activated and there is an increase as the body's immune defense system that functions to hold or get rid of potentially harmful foreign objects. However, based on the classification of severity in extra-pulmonary TB can affect the relationship of lymphocyte and monocyte levels that patients with severe TB will experience a decrease in the number of CD 4+ and CD $8+$. This is a sign of suppression of cellular immunity in patients.
\end{abstract}

Keywords : Lymphocyte, Monocyte, Extra-Pulmonary TB

\begin{abstract}
Abstrak: Hubungan Kadar Limfosit dan Monosit dengan Tingkat Keparahan Pada Pasien Tuberkulosis Ekstra Paru. Tuberkulosis (TB) masih merupakan masalah kesehatan di dunia yang menempati urutan kedua sebagai penyakit infeksi penyebab kematian terbanyak setelah Human Immunodeficiency Virus (HIV). Mycobacterium tuberculosis menyerang organ paru-paru $80 \%$, sedangkan $20 \%$ lainnya menyerang organ luar paru seperti selaput otak, tulang, ginjal, rongga perut, kelenjar getah bening ataupun bagian tubuh lainnya termasuk kulit dan pleura. Penyebaran TB ke organ ekstra paru tergantung pada sistem kekebalan tubuh seluler, terutama sel $\mathrm{T}$ - helper (respon TH1). Imunitas seluler lebih berperan aktif daripada humoral dikarenakan imunitas seluler sebagai fungsi utama leukosit diaktifkan dan terjadi peningkatan sebagai sistem pertahanan imun tubuh yang berfungsi untuk menahan atau menyingkirkan benda asing yang berpotensi merugikan. Namun, berdasarkan klasifikasi tingkat keparahan pada TB ekstra paru dapat mempengaruhi hubungan kadar limfosit dan monosit bahwa pasien TB berat akan mengalami penurunan jumlah CD $4+$ dan $C D 8+$. Hal ini merupakan tanda terjadinya supresi imunitas seluler pada pasien.
\end{abstract}

Kata Kunci : Limfosit, Monosit, Tuberkulosis Ekstra Paru

\section{PENDAHULUAN}

Tuberkulosis (TB) adalah penyakit menular yang disebabkan oleh bakteri Mycobacterium tuberculosis. TB ditransmisikan melalui droplet nuclei yang dikeluarkan oleh penderita TB aktif ketika batuk, bersin, atau berbicara. TB masih merupakan masalah kesehatan di dunia, yang menempati urutan kedua sebagai penyakit infeksi penyebab kematian terbanyak setelah (HIV) (Dotulong, 2015). kasus baru TB dengan insiden sekitar 122 per 100.000 penduduk.

Pada tahun 2012 insiden tertinggi ditemukan di ASIA (58\%) dan Afrika (27\%). Indonesia masuk dalam 10 negara dengan insiden TB tertinggi mulai dari India, China, Afrika Selatan, dan Indonesia menduduki posisi 
keempat pada tahun 2012 (Dotulong, 2015). Kasus tuberkulosis di Indonesia pada tahun 2015 paling banyak ditemukan pada kelompok umur 25-34 tahun yaitu sebesar $18,65 \%$ diikuti kelompok umur 45-54 tahun sebesar $17,33 \%$ dan pada kelompok umur 3544 tahun sebesar $17,18 \%$ (Kemenkes RI tahun 2015). Di Provinsi Lampung, insiden kasus TB dari tahun ke tahun mengalami peningkatan, seperti pada penelitian yang telah dilakukan pada daerah Lampung khususnya metro penderita TB di Kota Metro Lampung lebih dari 1000 tiap tahunnya dan kurang dari $10 \%$ adalah penderita dengan Bakteri Tahan Asam (BTA) positif (Rachmawati, 2015).

$$
\text { Menurut World }
$$

Health

Organization (WHO) pada tahun 2012, memperkirakan bahwa jumlah kasus TB di dunia 8,6 juta Berdasarkan klasifikasi secara patologis TB dibedakan menjadi dua yaitu: TB primer adalah partikel infeksi terhisap pada manusia yang sehat sedangkan TB sekunder adalah bakteri yang bersifat dormant (tidur) pada TB primer yang akan muncul bertahun-tahun kemudian sebagai infeksi endogen menjadi TB dewasa dikarenakan imunitas tubuh menurun. Keluhan secara umum pada pasien tuberkulosis paru, yaitu demam, malaise berat badan turun, dan rasa lelah, sedangkan keluhan pada pernapasannya yaitu batuk darah, sesak nafas, nyeri dada dan sering terkena flu (Sudoyo, 2014).

Mycobacterium tuberculosis paling banyak menyerang organ paru-paru pada manusia karena paru-paru merupakan organ yang langsung berinteraksi dengan lingkungan di luar tubuh manusia dan menyebabkan infeksi sedangkan yang terkena pada organ di luar paru-paru seperti menyerang selaput otak, tulang, ginjal, rongga perut, kelenjar getah bening ataupun bagian tubuh lainnya termasuk kulit dan pleura (Jordi, 2018). Penyebaran TB ke organ ekstra paru tergantung pada sistem kekebalan tubuh seluler, terutama sel $\mathrm{T}$ - helper (respon TH1). Sel $T$ dan makrofag membentuk granuloma terutama terdiri dari makrofag dan limfosit dengan pusat nekrotik (pusat caseous). Granuloma berfungsi untuk mencegah pertumbuhan lebih lanjut dan penyebaran Mycobacterium tuberculosis (Azizi, 2014).

Pemeriksaan hitung jenis leukosit dapat digunakan untuk menunjang diagnosis infeksi TB khususnya pada penelitian yang akan saya lakukan pada limfosit dan monosit karena fungsi utama limfosit untuk mengenali dan menghilangkan ancaman bagi tubuh. Terdapat dua jenis limfosit, limfosit B (menghasilkan antibodi yang bertanggung jawab dalam imunitas humoral atau yang diperantarai oleh antibodi) dan Limfosit $\mathrm{T}$ (tidak memproduksi antibodi, sel ini secara langsung menghancurkan sel sasaran spesifiknya dengan beragam zat kimia atau yang dinamakan imunitas seluler). Sedangkan, pada monosit fungsi utamanya memproses dan mempresentasikan antigen. Peningkatan monosit biasanya terjadi karena infeksi penyakit granulosit dan gangguan mieloproliferatif (Suciyani, 2017).

Tujuan penelitian ini adalah untuk mengetahui hubungan kadar limfosit dan monosit dengan tingkat keparahan pada pasien tuberkulosis ekstra paru. METODE

Dengan cara mengumpulkan beberapa artikel ilmiah penelitian sebelumnya untuk mendapatkan informasi dan membuat ringkasan berupa review artikel ilmiah.

\section{HASIL}

Sistem imun merupakan sistem pertahanan tubuh terhadap benda asing atau patogen. Sistem imun manusia terdiri dari imunitas alami dan adaptif. Imunitas alami sudah ada dan berfungsi sejak lahir, imunitas ini memiliki respons langsung dan cepat terhadap adanya patogen pada individu yang sehat (Baratawidjaja, 2013).

Imunitas ini berperan sebagai lini pertama pertahanan tubuh terhadap patogen tanpa diperlukan pajanan sebelumnya, karena tidak 
spesifik imunitas ini tidak adekuat untuk melawan patogen yang potensial. Imunitas ini dibagi menjadi imunitas humoral dan seluler. Komponen yang berperan dalam imunitas humoral adalah komplemen, interferon, protein fase akut, dan kolektin. Sedangkan pada imunitas seluler komponen yang berperan adalah sel fagosit mononuklear dan polimorfonuklear, sel natural killer (NK) serta sel mast (Baratawidjaja, 2013).

Imunitas adaptif mempunyai kemampuan untuk mengenali patogen. Pada pajanan yang pertama, patogen akan dikenali dan terjadi sensitisasi sel imun yang berperan pada imunitas ini. Setelah adanya sensitisasi, patogen yang terpajan kembali akan lebih cepat dikenali dan dihancurkan. Sama halnya dengan imunitas alami, imunitas adaptif juga dibagi menjadi imunitas humoral dan seluler yang masing-masing diperankan oleh sel limfosit B dan limfosit $T$ (Abbas, 2013).

Mycobacterium

tuberculosis

merupakan bakteri intraseluler. Bakteri ini berbentuk batang dan bersifat tahan asam. Mycobacterium tuberculosis 64 (MPT64) merupakan protein yang dihasilkan oleh salah satu protein terbaik ditandai antigen dari wilayah RD2, mampu menginduksi tingkat tanggapan Interferon (IFN) yang tinggi pada pasien (Pomandia, 2017).

Bakteri yang masuk ke paru-paru akan difagosit oleh makrofag kemudian dihancurkan. Epitop dari hasil penghancuran bakteri tersebut akan berikatan dengan protein pada membran makrofag yaitu Major Histocompatibility Complex (MHC) kelas I dan II untuk dipresentasikan ke sel limfosit $T$, kemudian terjadi aktivasi dan proliferasi limfosit T. Respon imun utama terhadap bakteri intraseluler yaitu Cell Mediated Immunity (CMI). Mekanisme imunitas ini diperankan oleh sel limfosit $T$ tetapi fungsi efektornya untuk eliminasi bakteri diperankan oleh makrofag yang diaktivasi oleh sitokin yang diproduksi sel T (Suciyani, 2017).
Imunitas yang diperantarai sel T berperan mungkin dalam infeksi Mycobacterium tuberculosis (Ahmad, 2017). Imunitas seluler lebih berperan aktif daripada humoral dikarenakan imunitas seluler sebagai fungsi utama leukosit diaktifkan yaitu sebagai sistem pertahanan imun tubuh yang berfungsi untuk menahan atau menyingkirkan benda asing yang berpotensi merugikan. Maka dari itu respon imun alami yang terjadi terhadap bakteri intraseluler adalah fagositosis, namun karena bakteri intraselular relatif resisten terhadap degradasi dalam makrofag, menyebabkan tidak efektifnya respon imun alami sehingga infeksi menjadi kronik (Suciyani, 2017).

Terdapat dua jenis limfosit yaitu, limfosit B (menghasilkan antibodi yang bertanggung jawab dalam imunitas humoral atau yang diperantarai oleh antibodi) dan Limfosit $T$ (tidak memproduksi antibodi, sel ini secara langsung menghancurkan sel sasaran spesifiknya dengan beragam zat kimia atau yang dinamakan imunitas seluler). Sedangkan pada monosit fungsi utamanya

memproses dan mempresentasikan antigen. Peningkatan monosit biasanya terjadi karena infeksi penyakit granulosit dan gangguan mieloproliferatif (Suciyani, 2017).

Berdasarkan judul jurnal yaitu Hubungan Kadar Limfosit dan Monosit dengan Tingkat Keparahan Pada Pasien Tuberkulosis Ekstra Paru. Tuberkulosis Ekstra Paru dibagi berdasarkan pada tingkat keparahan penyakitnya sesuai dengan letak anatomi, yaitu: a. TB Ekstra Paru Ringan (misalnya: TB kelenjar limpha, pleuritis eksudativa unilateral, tulang kecuali tulang belakang, sendi, dan kelenjar adrenal) b. TB Ekstra Paru Berat (misalnya: meningitis, millier, perikarditis, peritonitis, pleuritis eksudativa duplex, TB tulang belakang, TB usus, TB alat kelamin) (Kowalak,2011).

Mycobacterium tuberculosis yang menyerang organ Ekstra paru berhubungan dengan adanya factor genetic yaitu NRAMP1 dan faktor lingkungan serta jumlah CD4 yang 
rendah.

Kasus

tuberkulosis

polimorfisme yang berkembang karena tidak adanya respon imun yang efektif. Pada gen NRAMP 1 (Natural Resistance Associated Macrophage Protein-1) adalah protein transmembran yang ditemukan di endosom dan lisosom yang berfungsi memompa kation divalent (misalnya $\mathrm{Fe}^{2+}$ ) dari lisosome tersebut. Gen NRAMP1 dapat menghambat pertumbuhan mikroba dengan membatasi ketersediaan ion yang dibutuhkan oleh bakteri (Azizi, 2014).

Menurut penelitian yang

dilakukan oleh Azzahra (2017) mengenai pengaruh jumlah hitung jenis limfosit dan monosit yaitu didapatkan bahwa pasien TB berat mengalami penurunan jumlah $\mathrm{CD}^{+}$dan $\mathrm{CD} 8+$. Hal ini merupakan tanda terjadinya supresi imunitas seluler pada pasien. Akan tetapi mereka belum dapat menyimpulkan apakah penurunan $\mathrm{CD} 4+$ dan $\mathrm{CD} 8+$ ini disebabkan oleh TB atau malah sebagai faktor predisposisi terjadinya TB (Azzahra, 2017).

Penurunan ini terjadi pada pasien dengan TB berat yang ditandai dengan adanya kadar serum albumin yang rendah, hematokrit yang rendah, indeks massa tubuh yang rendah, atau gambaran radiologi TB paru yang luas. Penjelasan yang paling mungkin yaitu pasien dengan TB berat kemungkinan besar mengalami penurunan jumlah limfosit total dan CD4+ dan pada penelitian ini juga dijelaskan bahwa TB paru ringan jumlah limfosit normal, kemungkinan hal ini terjadi pasien tidak mengalami adanya penurunan kadar albumin, hematokrit, dan indeks masa tubuh serta tidak adanya gambaran radiologi TB paru yang luas (Suciyani, 2017).

Penelitian lain telah menunjukkan bahwa penurunan limfosit ini dapat kembali normal setelah pemberian terapi anti tuberkulosis selama 1 bulan. Didapatkan juga pada penelitian yang dilakukan oleh Brenda dkk penurunan jumlah CD4+ pada pasien TB HIV-negatif (Suciyani, 2017).

\section{PEMBAHASAN}

Pada infeksi bakteri intraseluler seperti Mycrobacterium tuberculosis tubuh tidak dapat melawan dengan hanya mengandalkan imunitas alami tapi juga membutuhkan imunitas adaptif terutama imunitas seluler yang diperankan oleh sel limfosit T. Limfosit $T$ dibentuk di sumsum tulang, proliferasi dan pematangannya terjadi di dalam organ timus sebagai organ limfoid primer, sel-sel itu kemudian masuk ke peredaran darah menuju ke jaringan/organ limfoid sekunder untuk bermukim sementara dan kemudian dilanjutkan dengan bermigrasi lagi ke peredaran darah. Limfosit $\mathrm{T}$ dengan subpopulasi Th $(\mathrm{CD} 4+)$ dan Tc (CD8+) akan berpartisipasi dalam respons imun adaptif khususnya respons imun seluler. Awalnya sel-sel ini merupakan naif yang dapat berubah menjadi sel efektor saat teraktivasi. Sel akan teraktivasi apabila terdapat ikatan antara ligan (epitop+MHC) yang disajikan oleh APC dengan reseptor yang ada pada permukaan limfosit $T$ itu sendiri (Abbas, 2013).

Fungsi utama respons imun seluler adalah pertahanan terhadap bakteri intraseluler, virus, jamur, parasit, dan keganasan. Sel $\mathrm{T}$ terdiri atas beberapa subset dengan fungsi yang berbeda yaitu sel $\mathrm{T}$ helper 1 (Th1), $T$ helper 2 (Th2), T delayed-type hypersensitivity (Tdth), cytotoxic T lymphocyte (CTL atau Tc), regulatory $T$ lymphocyte (Th3 atau Tregs). Cluster of differentiation 4 (CD4+) merupakan penanda bagi sel $\mathrm{T}$ helper dan cluster of differentiation 8 $(\mathrm{CD} 8+)$ merupakan penanda dari cytotoxic $T$ lymphocyte yang terdapat pada membran protein sel (Baratawidjaja, 2013).

Fungsi dari masing-masing subset yaitu: a. $T$ helper (mengenali antigen yang disajikan oleh APC dan juga sekresi sitokin yang akan merangsang mekanisme imunitas lain dan juga respons inflamasi) b. T cytotoxic (mengenali antigen pada sel yang terinfeksi dan akan membunuh sel yg terinfeksi tersebut apoptosis) c. T regulator (menekan dan mencegah 
respons imun pada antigennya sendiri) d. Natural killer (mengenali antigen dan membunuh sel yang terinfeksi)(Baratawidjaja, 2013).

Limfosit B atau sel B berperan dalam sistem imun spesifik humoral yang akan menghasilkan antibodi. Sel B akan teraktivasi dengan pajanan antigen oleh APC melalui MHC kelas II yang kemudian berproliferasi dan berdiferensiasi menjadi sel plasma yang dapat memproduksi antibodi spesifik. Fungsi utama antibodi yaitu sebagai pertahanan terhadap infeksi ekstraseluler, virus dan bakteri serta menetralisir toksin yang dihasilkan oleh bakteri. Sel B memiliki reseptor yang spesifik untuk tiap molekul antigen dan dapat dideteksi melalui metode tertentu melalui marker seperti cluster of differentiation 19 (CD19+), cluster of differentiation 21 (CD21+) dan MHC II. (Baratawidjaja, 2013).

Peningkatan jumlah limfosit atau limfositosis dapat menunjukkan adanya respon inflamasi terhadap bakteri penyebab penyakit TB dan menunjukkan adanya proses penyembuhan TB. Interleukin-2 yang telah merangsang limfosit $T$ yang menjadi sel $T$ reaktif terhadap Mycobacterium tuberculosis kemudian akan menghasilkan IFN, TNF, IL-2, IL4, IL-5, IL-10 sama dengan sitokin yang dihasilkan oleh sel $T$, selain itu supernatan dari sel $T$ yang dirangsang oleh Mycobacterium tuberculosis akan meningkatkan agregasi makrofag dan selanjutnya berperan pada pembentukan granuloma. Makrofag yang teraktivasi menunjukkan peningkatan fungsi dalam fagositosis (Wirawan, 2011).

Meningkatnya jumlah monosit dapat terjadi karena sel monosit yang berperan penting dalam respon imun pada infeksi $T B$, sehingga saat bakteri penyebab penyakit TB ini masuk ke dalam tubuh monosit memperbanyak diri untuk memfagositkannya. Bakteri Mycobacterium tuberculosis penyebab penyakit TB ini memiliki fosfolipid pada selnya,sehingga sebagian fosfolipid dari Mycobacterium tuberculosis ini mengalami degradasi oleh sel monosit dan makrofag yang ada di dalam jaringan yang menyebabkan transformasi sel-sel tersebut menjadi sel epiteloid. Monosit merupakan sel utama dalam pembentukan tuberkel. Aktivasi pembentukan tuberkel ini dapat tergambar dengan adanya monositosis di dalam darah. Monosit merupakan sel utama dalam pembentukan tuberkel. Aktivasi pembentukan tuberkel ini dapat tergambar dengan adanya monositosis di dalam darah (Oehadin, 2003).

\section{KESIMPULAN}

Dari beberapa jurnal mengenai hubungan kadar limfosit dan monosit dengan tingkat keparahan pada pasien TB ekstra paru yaitu didapatkan bahwa pasien dengan tingkat keparahan TB ekstra paru berat mengalami penurunan jumlah CD 4+dan CD 8+ Hal ini merupakan tanda terjadinya supresi imunitas seluler pada pasien. Penurunan ini terjadi pada pasien dengan TB berat yang ditandai dengan adanya kadar serum albumin yang rendah, hematokrit yang rendah, indeks massa tubuh yang rendah, atau gambaran radiologi TB paru yang luas sedangkan TB paru ringan jumlah limfosit normal, pasien tidak mengalami adanya penurunan kadar albumin, hematokrit, dan indeks masa tubuh serta tidak adanya gambaran radiologi TB paru yang luas.

\section{SARAN}

Perlu dilakukan penelitian lebih lanjut dan spesifik mengenai hubungan sistem imunitas seluler dengan tingkat keparahan pada pasien tuberkulosis ekstra paru untuk mengetahui kemungkinan lain yang terjadi untuk pengembangan ilmu pengetahuan.

\section{DAFTAR PUSTAKA}

Abbas AK., Lichtman AH., Pillai S. (2013). Cellular and molecular immunology. 7th rev. ed. Baker DL, ilustrator. Philadelphia: Saunders Elsevier. HIm. 350-415 Ahmad., Putri, O., Agus, Rosana., Masai, M.N., Ahyar. (2017). Produksi Protein Rekombinan 
Mpt64 Dari Mycobacterium tuberculosis Sebagai Immunodiagnostik Tuberkulosis Laten. Departemen Biologi Fakultas Matematika dan Ilmu Pengetahuan Alam. Makassar: Universitas Hasanuddin.

Azzahra, F. A. Profil limfosit pada pasien tuberkulosis paru kasus baru di RSUD Tangerang Selatan (Bachelor's thesis, UIN Syarif Hidayatullah Jakarta: Fakultas Kedokteran dan Ilmu Kesehatan, 2017).

Azizi, F. H., Husin, U. A., \& Rusmartini, T. (2014). Gambaran Karakteristik Tuberkulosis Paru Dan Ekstra Paru Di BBKPM Bandung Tahun 2014. Universitas Islam Bandung.

Baratawidjaja, K.G., Rengganis, I. (2013). Imunologi Dasar. Edisi ke-10. Jakarta; FKUI. HIm. 22233.

Dotulong, J., Sapulete, M. R., \& Kandou, G. D. (2015). Hubungan faktor risiko umur, jenis kelamin dan kepadatan hunian dengan kejadian penyakit TB Paru di Desa Wori Kecamatan Wori. Jurnal Kedokteran Komunitas dan Tropik, 3(2).

Kemenkes. (2015). Profil Kesehatan Indonesia 2015. Indonesia

Kowalak, J. P., Welsh, W., \& Mayer, B. (2011). Buku ajar patofisiologi. Jakarta: EGC, 233.

Oehadin, A. (2003). Aspek Hematologi Tuberkulosis. Bandung: Fakultas Kedokteran Universitas Padjadjaran. [Skripsi]

Pomandia, N. M., Waworuntu, O. A., \& Homenta, H. (2017). Hasil Diagnostik Mycobacterium tuberculosis pada Pasien Batuk $\geq 2$ Minggu dengan Pewarnaan Ziehl Neelsen di Poliklinik Interna RSU Pancaran Kasih Manado. eBiomedik, 5(2).

Rachmawati, F. (2015). Prevalensi Penyakit Tuberculosis Paru di Kota Metro Provinsi Lampung Tahun 2011-2013. Jurnal Biotek Medisiana Indonesia, 4(1), 2531.
Suciyani, S., Naim, N., \& Armah, Z. (2018). Analisis Kuantitas dan Hitung Jenis Leukosit pada Petugas Radiologi di Balai Besar Kesehatan Paru Masyarakat (BBKPM) Makassar. Media Kesehatan Politeknik Kesehatan Makassar, 12(1), 59-65.

Sudoyo AW., Setiyohadi B., Alwi I., Simadibrata. (2014). Buku Ajar Ilmu Penyakit Dalam. dalam Tuberkulosis Paru. Jilid II edisi V. Jakarta: Interna Publishing.

Wirawan, R. (2011). Pemeriksaan Laboratorium Hematologi. Jakarta : Badan Penerbit FKUI. 